\title{
Koncepcja wykorzystania interaktywnych prezentacji kartograficznych jako narzędzia w procesie edukacji geograficzno-historycznej
}

\author{
Teresa Bogacz, Beata Konopska
}

\section{Wprowadzenie}

Podstawowym celem każdej mapy jest dostarczenie informacji o obiektach, zjawiskach oraz terenie, na którym one występują w sposób czytelny i zrozumiały dla jej użytkownika. Autorzy map, przedstawiając jakiekolwiek zjawisko lub obiekt, używają znaków graficznych, które w sposób intuicyjny lub opisowy powinny być zrozumiałe dla odbiorcy. Jednakże poprawne odczytanie treści mapy możliwe jest po nabyciu elementarnej wiedzy z tego zakresu, głównie podczas edukacji szkolnej. Mapa jest formą komunikacji wizualnej, której efektywność przekazu jest miarą poprawności jej opracowania ${ }^{1}$. Dlatego przystępując do opracowania jakiejkolwiek mapy, w pierwszej kolejności należy określić jej przeznaczenie, tj. sformułować cel opracowania i scharakteryzować cechy odbiorcy. Pozwoli to na właściwy, zgodny z jego możliwościami percepcyjnymi, dobór zakresu treści mapy, znaków i metod kartograficznej prezentacji danych. Należy jednak pamiętać, że w przypadku edukacji szkolnej tym odbiorcą jest uczeń, który w zależności od etapu kształcenia wyróżnia się inną, związaną z jego rozwojem, percepcją.

Przedmiotem niniejszego opracowania stało się zatem przybliżenie ważnych dla tematu aspektów: jak powinien przebiegać proces wykorzystywania map jako środka komunikacji na różnych poziomach kształcenia, jak zdobycze technologiczne wpływają na unowocześnianie narzędzia, jakim jest mapa, oraz jak przekłada się to na potencjalną efektywność kształcenia i możliwości wykorzystywania nabytych przez

$1 \mathrm{~J}$. Olson, Experience and the improvement of cartographic communications, „Cartographic Journal”, 12, 1975, s. 94-108. Temu zagadnieniu autorka poświęciła większą część swojego artykułu. ucznia umiejętności w dalszej już praktyce pozaszkolnej. Zwrócono także uwagę na fakt, że w sytuacji, gdy zaciera się granica dzieląca nauki humanistyczne od przyrodniczych, ważne jest, aby w niedalekiej przyszłości w dydaktyce szkolnej pojawiła się koncepcja wspólnej mapy jako uniwersalnego narzędzia wykorzystywanego zarówno na lekcjach geografii, jak i historii.

Dla zobrazowania wymienionych wątków tematycznych sięgnięto po przykłady zarówno map tradycyjnych (drukowanych), jak i multimedialnych, coraz liczniejszych i korespondujących z nowoczesnym systemem nauczania poglądowego. Szczególną uwagę zwrócono na wszelkie przejawy łączenia na mapach aspektów historycznych i geograficznych.

\section{Mapa w dydaktyce geografii i historii}

Mapy, których dobór treści i zasad kartograficznej prezentacji podporządkowany został celom nauczania, nazywa się mapami szkolnymi. $\mathrm{Na}-$ leżą do nich - według tradycyjnej terminologii - mapy ścienne, podręczne i atlasowe. Ich opracowanie, z uwagi na stosowanie na wszystkich etapach nauczania, wymaga - w zależności od poziomu rozwoju ucznia - innego podejścia do wyboru treści i jej graficznego przedstawienia. Dobrze opracowane mapy, w myśl powyższych zasad, należą do niezbędnych środków dydaktycznych, które wspomagają proces komunikacji na poziomie szkolnym. Dydaktyka zarówno geografii, jak i historii pozostaje zatem na pograniczu tych dwóch dyscyplin (z racji przekazywanych treści) oraz nauk pedagogiczno-psychologicznych (z racji możliwości ich przyswajania).

Opracowania kartograficzne należą do systemu obrazów symbolicznych ze względu na 
fakt przedstawiania treści geograficznych lub historycznych za pomocą ustalonych symboli, nazywanych znakami kartograficznymi. W procesie komunikacji nauczyciel-uczeń podczas wyjaśniania zjawisk i procesów, mających miejsce w przestrzeni geograficznej, są najważniejszym ogniwem. Warto podkreślić, że mają nie tylko walory poznawcze, lecz spełniają również funkcje kształcące; wykorzystywane są w procesie budowania wyobraźni przestrzennej, nabywania umiejętności obserwacji, interpretacji obrazów symbolicznych, pojmowania zmienności zjawisk przestrzennych w czasie. Nadanie publikacjom kartograficznym rangi niezbędnych składników w systemie środków dydaktycznych pomocnych podczas nauczania geografii i historii wiąże się ze specyfiką mapy, która jest optymalnym kluczem do zrozumienia procesów nierozerwalnie związanych z przestrzenią, a w przypadku historii również z czasem.

Znajomość faktów przyswajanych poprzez mapy z obu dziedzin wiedzy - geografii i historii - może być bardzo przydatna zarówno w edukacji geograficznej, jak i historycznej. Nie ulega wątpliwości, że łatwiej będzie uczniom zrozumieć przejawy życia społeczno-gospodarczego we współczesnym świecie, jeśli otrzymają odpowiednie przygotowanie $\mathrm{z}$ historii. Podobnie - nie ulega wątpliwości - wiedza geograficzna jest przydatna w nauczaniu problematyki historycznej. Uczniowie lepiej opanują wiedzę przedstawioną na mapach historycznych, jeżeli na lekcjach geografii nauczą się czytania mapy i pomocniczo będą korzystać z map geograficznych. Wiedza o ukształtowaniu terenu i warunkach klimatycznych czy też układzie sieci hydrograficznej ułatwi im zrozumienie m.in. sekwencji zdarzeń wojennych, rozwoju osadnictwa lub zasadności podejmowanych decyzji politycznych. Między geografią i historią występuje wyraźna merytoryczna korelacja. Istotne jest jednak, aby daną treść najpierw wprowadzić w przedmiocie dla niej podstawowym, a później wykorzystać w drugim. Przy zachowaniu tej sekwencji mamy korelację programową. Jej zachwianie powoduje konieczność wprowadzenia do publikacji kartograficznych, zwłaszcza atlasów, rozwiązań zaburzających na przykład logikę układu treści. Między innymi na poziomie szkoły podstawowej wywołało to konieczność wprowadzenia do atlasu historycznego dla klasy IV problematyki związanej z powstawaniem map w ogóle 2 .

Wymogi odnoszące się do korelacji programowej i zacieśnianie połączeń geografii z historią wynikają także z głębszych przesłanek powiązanych z nowym modelem postrzegania świata i jego uwarunkowań. Holistyczne ujęcie przyrodoznawstwa oraz personalistyczny kierunek przyjęty w pedagogice i psychologii stały się podstawą geografii jako przedmiotu nauczania we współczesnej szkole. Nauczanie geografii pozwala zatem na odejście od wąskiego specjalistycznego opisu rzeczywistości i podążanie w kierunku wytłumaczenia zjawisk na tle szeroko pojmowanych relacji. Zgodnie z tą koncepcją przyjmuje się bowiem, że Ziemia wraz z żyjącymi na niej istotami jest tworem organicznym stanowiącym jedną całośćs. Takie podejście do przedmiotu geografii i historii pokazuje ich wzajemną zależność i merytoryczną kompatybilność. Ponieważ współczesne i istniejące w przeszłości obiekty topograficzne, wydarzenia społeczno-gospodarcze dawne i teraźniejsze tworzą logiczny ciąg obiektów badań charakteryzujących geoprzestrzeń, to kartografia jest naturalną płaszczyzną łączącą obie, bardzo już do siebie zbliżone dyscypliny naukowe. Wspominane już równoległe korzystanie z map geograficznych i historycznych jest zatem jak najbardziej uzasadnione.

Efektywność nauczania wzrasta, gdy w procesie edukacyjnym wykorzystywane są te same opracowania w formie map ściennych i atlasowych (lub podręcznych). Koncepcja takiego podejścia do nauczania wykorzystującego mapy jest niezwykle istotna w trakcie komunikacji nauczyciel-uczeń, ponieważ widzą oni tę samą treść na ścianie i na mapie w atlasie. Nie tylko ułatwia to proces uczenia (relacja nauczyciel-uczeń), ale jest również pomocne w toku utrwalania wiedzy samodzielnie $\mathrm{w}$ domu przez

\footnotetext{
${ }^{2}$ Atlas historyczny. Od starożytności do współczesności. Szkoła podstawowa, wyd. 1, Nowa Era, Warszawa 2012, s. 72.

3 S. Piskorz, Wprowadzenie, w: Zarys dydaktyki geografii, red. S. Piskorz, Warszawa 1997, s. 14-15.
} 
ucznia. W okresie PRL-u zarzucono te poglądy i opracowywano mapy ścienne uniwersalne, przeznaczone jednocześnie dla szkoły podstawowej, liceum i szkół wyższych. Jedynie mapy atlasowe były opracowywane zgodnie z podstawą programową i możliwościami percepcyjnymi uczących się. Podwójne opracowanie map do formy ściennej i atlasowej (podręcznej) ma znaczenie wyłącznie przy produktach papierowych. Mapy multimedialne czy internetowe $\mathrm{z}$ racji wykorzystywanej technologii ten warunek spełniają w sposób oczywisty (niemal automatycznie).

\section{Kształtowanie się relacji między geografią a historią na gruncie dydaktyki szkolnej}

W przypadku nauczania historii jako pierwszego, który poświęcił wiele uwagi roli mapy w procesie przekazywania wiedzy, wymienia się Joachima Lelewela (1786-1861). To dzięki niemu w szkolnictwie polskim zaczęto obok map geograficznych posługiwać się historycznymi; do tego czasu na lekcjach historii korzystano tylko z tych pierwszych. Już wtedy pojawiły się początki tego sposobu myślenia, który budował ludzkie działania w przestrzeni, krajobrazie i związkach z obszarem geograficznym ${ }^{4}$. W połowie XIX w. w oficynie wydawniczej Justusa Perthesa dr Karol Spruner opublikował szkolny atlas geograficzno-historyczny ${ }^{5}$, w Petersburgu Iwan Achmatow i Mikołaj Karamzin wydali atlas w podobnej koncepcji dla Rosji ${ }^{6}$, a we Francji propagatorem atlasów geograficzno-historycznych był Jan Franciszek Schrader, który w ostatniej dekadzie XIX w. w wydawnictwie Hachette opublikował atlasy do geografii współczesnej i historycznej ${ }^{7}$. Z polskich autorów koncepcję atlasów geograficzno-historycznych podjął Eugeniusz Romer, wydając w 1936 r. Atlas geograficzny i historyczny dla IV

\footnotetext{
4 S. Bednarek, Pojmowanie kultury i jej historii we współczesnych syntezach dziejów kultury polskiej, Wrocław 1995.

5 K. Spruner, Historisch-Geographischer Schul-Atlas, Gotha 1890.

6 I. Achmatow, M. Karamzin, Attas gieograficzeskij, istoriczeskij i chronotogiczeskij rossijskogo gosudarstwa, izd. E. Ejnerlinga, Sankt-Pietierburg 1845.

7 J.F. Schrader, Atlas de géographie moderne, Paris 1890; tenże, Atlas de géographie historique, Paris 1893.
}

klasy gimnazjum ${ }^{8}$. Wydaje się, że problematyka map historycznych została szerzej dostrzeżona przez metodyków dopiero w okresie międzywojennym ${ }^{9}$, czego przejawem była publikacja tegoż atlasu, łączącego geografię z historią współczesną. Jego autor - Eugeniusz Romer - uważał, że „dzieje nowożytne im bardziej zbliżają się do współczesnych, tym bardziej swą istotą oddalają się od dziejów, a stają się geografią"10.

Na łączenie geografii z historią miały również wpływ wydarzenia spoza sfery edukacyjnej, jak zmiany granic państwa. Miało to miejsce po odzyskaniu niepodległości przez Polskę i zaraz po drugiej wojnie światowej, kiedy to pojawiły się nawet zalecenia stosowania równolegle obu rodzajów map ${ }^{11}$. A zatem, mimo formalnego rozdzielenia dwóch przedmiotów nauczania, zdarzały się sytuacje, w których łączenie treści geograficznych $\mathrm{z}$ historycznymi ułatwiało procesy komunikacyjne.

W ewolucji map szkolnych w odniesieniu do zakresu i sposobu ujmowania treści można odnotować kilka etapów. W pierwszym, mniej więcej do końca XIX w., większość map geograficznych i historycznych przedstawiała treść ograniczoną do podstawowych elementów, jak: ukształtowanie terenu, linia brzegowa i hydrografia. Głównymi składnikami warstwy historycznej map w tym okresie były: schematycznie rytowane granice polityczne, osadnictwo i nazewnictwo. Pierwszą tematyką szczegółową były działania wojenne, wyprawy i miejsca bitew. Do końca okresu międzywojennego do nauki geografii i historii wprowadzone zostały zagadnienia gospodarcze i społeczne. Pojawienie się ich w atlasach geograficznych miało związek z rozwojem wiedzy w zakresie tej dyscypliny oraz z udoskonaleniem metod kartograficznych, natomiast $\mathrm{w}$ przypadku szkolnych map historycznych głównym powodem było odzyskiwa-

\footnotetext{
8 E. Romer, Atlas geograficzny i historyczny dla IV klasy gimnazjum, Książnica-Atlas, Lwów 1936

9 H. Mościcki, Wskazówki praktyczne dla nauczycieli historii w szkotach średnich i powszechnych, Warszawa 1925.

10 Tenże, Rola mapy w nauce o Polsce współczesnej, Lwów 1936 , S. 43.

11 C. Grot, Jakich map należy używać na lekcjach historii, „Życie Szkoły", 8/9, 1946, s. 197-199.
} 
nie niepodległości przez Polskę. Z kolei okres po drugiej wojnie światowej był czasem podejmowania obszernych przedsięwzięć realizowanych przez interdyscyplinarne zespoły badawcze. Zakres tematyki oraz zmiany w ilości i sposobach przedstawiania poszczególnych elementów treści map wynikały przede wszystkim z osiagnięć badawczych w zakresie geografii, historii, geografii historycznej oraz kartografii ogólnej.

Przeobrażenia polityczne po 1989 r. uwolniły szereg treści, których nie przedstawiano na mapach po drugiej wojnie światowej. Z kolei tworzące się warunki do rozwoju gospodarki wolnorynkowej sprzyjały powstawaniu wydawnictw, które w swoim profilu przewidywały również publikacje kartograficzne. Na różnych poziomach nauczania pojawiły się mapy tematyczne wnoszące do kartografii szkolnej nowe treści, w tym dotyczące dziedzictwa kulturowego, problemów finansowych czy zagadnień ekologicznych ${ }^{12}$.

Równolegle $\mathrm{z}$ przemianami ustrojowymi i mentalnymi następowała ekspansja na polski rynek nowoczesnych technologii - zwłaszcza multimedialnych i Internetu - które rozszerzyły możliwości komunikacji poprzez wprowadzenie do dydaktyki m.in. map interaktywnych. Mapy rozwojowe, porządkujące fakty i zjawiska linearne w czasie, przy zastosowaniu nowych technik uzyskały nową jakość $\mathrm{w}$ formie wielopłaszczyznowości i możliwości faktycznie dynamicznego przedstawienia zmienności zjawiska w czasie. W procesie komunikacji zwiększyło to siłę oddziaływania na wyobraźnię ucznia.

\section{Technologia wykonania mapy a sprawność procesu komunikacji}

Trudno już dzisiaj wyobrazić sobie efektywną edukację bez wykorzystania nowych technologii. Przedstawiciele pokolenia C (urodzeni po 1990 r.) nie pamiętają świata bez Internetu i komputerów. Jednocześnie ci młodzi ludzie mają opinię bardzo kreatywnych, co w znacznym stopniu wspomagane jest właśnie przez powszechny dostęp do nowych technologii. W ramach projektu „Start w karierę" Uniwersytet Łódzki przeprowadził sondaż wśród 259 uczniów szkół ponadgimnazjalnych w woje- wództwie łódzkim ${ }^{13}$. Wynika z niego, że prawie wszyscy $(91,5 \%)$ ankietowani młodzi ludzie korzystają z mediów społecznościowych, niemal połowa gra $\mathrm{w}$ gry komputerowe, ponad $14 \%$ prowadzi blogi. Co trzeci badany przyznał, że maluje, rysuje lub tworzy grafiki, animacje i strony internetowe. Ci ludzie określani są mianem „digital natives”, ponieważ narzędzia z zakresu IT wykorzystują na co dzień i są najbardziej aktywnymi użytkownikami Internetu. Nie ulega wątpliwości, że w życiu codziennym młodych ludzi znaczącą rolę odgrywają dzisiaj: komputer, Internet, e-maile i SMS-y. Ten fakt można już tylko skonstatować, a w dyskusji jedynie zadać pytanie - jak dalece i w jakich obszarach młodzi ludzie utożsamiają się z nowymi mediami albo jaką dostrzegają alternatywę dla kolejnych, nowszych technologii. Te nowoczesne narzędzia wydają się jednak wciąż jeszcze bardziej służyć rozrywce niż uczeniu się. Badania wśród gimnazjalistów wykazały, że częściej wykorzystują oni komputer do zabawy i komunikacji ze znajomymi niż do szukania informacji, słuchania (ściągania) muzyki i nauki ${ }^{14}$.

Nie można zatem kwestionować faktu, że nowe technologie dają szerokie możliwości komunikacyjne; są one chętnie używane, jeśli tylko jest do nich dostęp. Dzięki rozwojowi sieci teleinformatycznych możliwe jest przeglądanie baz danych geograficznych na całym świecie. Mapy i atlasy multimedialne zawierają szereg dodatkowych danych wynikających z możliwości technicznych, jakie stwarza ta forma prezentacji. Interaktywne mapy są zazwyczaj połączone z ilustracją statyczną (ikonografia) lub dynamiczną (modele 3D, fragmenty filmów popularnonaukowych, podróżniczych, dokumentalnych lub, choć rzadziej, fabularnych) oraz dźwiękiem. Najważniejsze procesy i zjawiska przedstawione

\footnotetext{
12 W. Ostrowski, Nowe mapy tematyczne w atlasach szkolnych PPWK, „Polski Przegląd Kartograficzny”, 33 (3), 2001, s. 231-234.

13 Młodzi ludzie, urodzeni po 1990 roku, wybierają kreatywny styl życia (http://natablicy.pl/mlodzi-Iudzie-urodzeni-po-1990-roku-wybieraja -kreatywny-styl-zycia,artykul.html?material id $=4$ feadb36142d5c8 269000000\# zamknii, dostęp: 14.08.2014).

${ }_{14} \mathrm{~A}$. Kamińska, Rola nowych technologii w nauczaniu - przykład fizyki, w: Nowe media w edukacji, red. T. Lewowicki, B. Siemieniecki, Toruń 2012, s. 51.
} 
na mapach są komentowane $\mathrm{w}$ formie do odsłuchania lub do samodzielnego przeczytania. Zazwyczaj cała zawartość ma możliwość wydrukowania. Większość tego rodzaju pomocy dydaktycznych zawiera też zestawy dodatkowych materiałów, które pozwalają przybliżyć trudny język mapy. W nauczaniu geografii w procesie czytania mapy wyobrażenie przestrzeni geograficznej powstałe pod wpływem systemu znaków użytych na mapie jest konfrontowane z rzeczywistością geograficzną. W przypadku nauczania historii jednak o wiele trudniej jest odnieść wyobrażenie powstałe w wyniku czytania mapy do obiektów już nieistniejących w rzeczywistości. W tych przypadkach połączenie z bazami ikonograficznymi, fragmentami filmów dokumentalnych lub fabularnych odgrywa niebagatelną rolę w usprawnieniu komunikacji i uczeniu języka mapy.

Multimedia łączą wiele środków przekazu: film wideo, animacje, tekst, obrazy, narrację, muzykę oraz inne dźwięki. Interaktywny charakter programów pozwala użytkownikowi na przeglądanie i wyszukiwanie informacji z możliwością powrotu do tych najbardziej przydatnych w danej chwili. Każda wyszukana informacja może być przekazana w różny sposób, wzbogacona filmem lub dźwiękiem. Powoduje to zwiększenie zainteresowania penetrowaną tematyką, zwiększa stopień zapamiętania i zrozumienia wyszukanych informacji oraz atrakcyjność ich uzyskiwania. Media dla współczesnej edukacji stanowią niezastąpione źródło informacji, narzędzie pracy intelektualnej, zarówno dla ucznia, jak i nauczyciela.

Możliwości nowych technologii są dziś brane pod uwagę w trakcie przygotowywania map, by nadać im formę obrazu dynamicznego i interaktywnego. Proces komunikacji w porównaniu z mapą statyczną jest o wiele bardziej efektywny. W krótszym czasie i w sposób bardziej atrakcyjny dla ucznia można przekazać więcej treści. Mapa statyczna bez względu na nośnik (wydrukowana na papierze lub prezentowana w formacie rastrowym na ekranie komputera) jest dziś dla młodego człowieka mało atrakcyjną formą przekazu. Niemniej mapa papierowa zawieszona na ścianie w gabinecie geograficz- nym czy historycznym jak żadna inna postać przestrzeni zapada w pamięć.

Internet, czyli kombinacja sieci, ludzi, którzy jej używają, programów służących do uzyskiwania informacji i sama informacja, stwarza - obok klasycznych metod nauczania wykorzystujących statyczne techniki prezentacji i wizualizacji (mapy i atlasy papierowe czy foliogramy) - nowe możliwości z wykorzystaniem techniki komputerowej. Nowe technologie informacyjne sprzyjają koncepcji aktywnego nauczania, na które składają się: współpraca $\mathrm{z}$ innymi członkami grupy, aktywna obecność w grupie, pełna kontrola nad otoczeniem oraz poczucie wolności wyboru i działania ${ }^{15}$.

Rolę Internetu w aktywizacji uczniów i pobudzaniu ich kreatywności podnoszą też sami nauczyciele. Spektrum korzyści nakreśla jedna z wypowiedzi: „W pracy z programem multimedialnym uczeń nie tylko ma możliwość obserwacji, ale swoim działaniem kreuje po części ekranową rzeczywistość. Ma świadomość aktywnego uczestnictwa w zajęciach, dokonuje wyboru fragmentów, sam układa kolejność przyswajanych problemów, współpracuje. Pozostawienie dużej swobody wzbudza w nim poczucie odpowiedzialności, a nawet wolności w (zdaniem uczniów), obwarowanej zakazami do granic możliwości, szkole"16. Media dla współczesnej edukacji stanowią niezastąpione źródło informacji, narzędzie pracy intelektualnej, zarówno dla ucznia, jak i nauczyciela.

\section{Mapa jako nośnik informacji i narzędzie komunikacji nauczyciel-uczeń}

\section{Komunikacja jako zjawisko społeczne}

W aspekcie społecznym komunikacja jest procesem, w ramach którego „ludzie dzielą się ze sobą myślami, wyobrażeniami i uczuciami w sposób powszechnie zrozumiały" ${ }^{17} \mathrm{w}$ różnych obszarach swego funkcjonowania, jak polityka,

\footnotetext{
${ }^{15} \mathrm{~A}$. Jelonek, Rola masmediów i Internetu w dydaktyce (http://www. nauczyciele.mom.pl/publikacje/10/strona6.html, dostęp: 14.08.2014).

16 R. Rippel, Multimedia w edukacji polonistycznej, „Forum Humanistów", 2, 2000, s. 25.

$17 \mathrm{Ch}$. Hamilton, Skuteczna komunikacja w biznesie, red. T. Rzepko, Warszawa 2011, s. 26.
} 
gospodarka, nauka, oświata. Przy tym każdy, od kogo wychodzi komunikat, wpływa bezpośrednio na inną osobę oraz oddziałuje na dalszy przebieg procesu komunikacyjnego.

Dzisiaj nie ulega wątpliwości, że aktualny stan procesu globalizacji jest związany przede wszystkim z rozwojem technicznych środków przekazu wiedzy, myśli i konkretnych rozwiązań. Dzięki nowym możliwościom komunikacji związanym z pojawieniem się narzędzi interaktywnych (przekaz cyfrowy, czy dynamiczne interfejsy) przyspieszeniu ulega proces indywidualizacji uczestnictwa $\mathrm{w}$ globalnym obiegu komunikacyjnym. Interaktywne instrumenty pozwalają użytkownikom na zwrotne wyrażanie oczekiwań oraz swobodny wybór treści, do których chcą dotrzeć lub które chcą otrzymywać $^{18}$.

\section{Komunikacja w kartografii szkolnej}

Wszystkie mechanizmy decydujące o rozwoju zarówno narzędzi, jak i metod posługiwania się nimi w procesie społecznej komunikacji znajdują swoje odzwierciedlenie także na gruncie kartografii. Efektywność komunikacji jest zapewniona wówczas, gdy obie strony - nadawca informacji i jej odbiorca - mają wcześniej ustalony sposób jej przetwarzania ${ }^{19}$. Dla ludzi są to języki, dla komputerów - protokoły komunikacyjne, dla map - znaki kartograficzne. W kartografii za ich pomocą zapisywana jest informacja o przestrzeni geograficznej. Wydaje się, że w przypadku nowoczesnych technologii do sygnałów mających odniesienie w kartografii obok znaków graficznych dochodzą dodatkowe, to znaczy sygnały dźwiękowe, podnoszące efektywność komunikowania się. To pozwala nauczycielowi prowadzić narrację na podstawie mapy i równocześnie wyświetlać na ekranie obrazy, fragmenty filmów dokumentalnych czy fabularnych, uruchamiać dodatkowe dźwięki itp.

Każda $\mathrm{z}$ form multimedialnych map daje różne możliwości stymulacji procesów uwagi poprzez oddziaływanie na różne zmysły. Dobór różnego rodzaju form gwarantuje pełen wachlarz bodźców aktywujących uczniów. Niemniej proces komunikacji powinien być tak skonstruowany, aby był przez nich łatwo odbierany. Mapy dynamiczne lub multimedialne pozwalają zjawisko prezentować wielokrotnie, powtarzając je tyle razy, ile wymaga tego pełen proces komunikacji. Ułatwia go również właściwy sposób przygotowania znaków kartograficznych, zarówno punktowych, liniowych, jak i powierzchniowych. Aby efekt komunikacji był optymalny, konieczne jest dostosowanie rodzaju przedstawień do poziomu percepcji ucznia. Do nauczania najmłodszych wykorzystywane są sygnatury obrazkowe, które swym kształtem wyraźnie nawiązują do przedstawianych obiektów. Do poziomu gimnazjum i wyżej zazwyczaj stosowane są sygnatury symboliczne, których kształt w sposób intuicyjny kojarzony jest z przedstawianym obiektem. Występuje tu wyraźny związek z narracją stosowaną w podręcznikach, która jest dostosowywana do poziomu percepcji odbiorcy.

\section{Interpretacja mapy w procesie komunikacji szkolnej}

\section{Znak i jego znaczenie w ujęciu słownym i przestrzennym}

Zasadniczym środkiem społecznej komunikacji, podstawowym elementem kultury ludzkiej oraz warunkiem istnienia wiedzy jest język. W kontekście lingwistycznym nauka o systemach znakowych, czyli semiotyka (semiologia), oprócz ujęcia słownego i kodów pozajęzykowych obejmuje także takie dziedziny, jak rozmaite formy społecznego komunikowania się (m.in. ceremonie, ubiory, szyldy) oraz kody estetyczne (literatura, sztuki plastyczne) ${ }^{20}$. W rozumieniu ogólnym semiotyka zajmuje się teorią znaku, typologią różnych postaci znaków oraz zagadnieniami jej istoty i roli, jaką pełnią w społeczeństwie w procesie wzajemnego poro-

\footnotetext{
18 P. Krajewski, Postrzeganie świata jako funkcja techniki, w: KulturaNauka-Media. Jak media transformują świat? Szanse i zagrożenia, red. P. Rudzki, Wrocław 2002, s. 60.

19 Por. D.R. Montenello, Cognitive map-design research in the twentieth century: Theoretical and empirical approaches, „Cartography and Geographic Information Science”, 29 (3), 2002, s. 283-304.

${ }^{20}$ Encyklopedia wiedzy o języku polskim, red. S. Urbańczyk, WrocławWarszawa-Kraków 1978, s. 299.
} 
zumiewania się. Znaczenie i zmiany znaczeniowe wyrazów (znaków) określa semantyka.

Także mapa ma swój specyficzny język, a o możliwościach skutecznego komunikowania się za jego pośrednictwem decydują znaki kartograficzne wraz z przypisanym im znaczeniem, adekwatnym do określonego poziomu nauczania, który wyznaczają możliwości percepcyjne ucznia. Katalog znaków, jakimi posługują się kartografowie, jest dość zasobny; tworzą go modyfikacje znaków punktowych - dotyczących informacji o punktowych obiektach nie w płaszczyźnie obrazu, wielkość oraz zmiany natężenia barwy) oraz zmienne różnicujące obraz (ziarnistość, kierunek, kształt). Wykorzystując naturalne cechy zmiennych graficznych, można wyraźnie wskazywać relacje zachodzące między obiektami, jak: podobieństwo, różnice, uporządkowanie i proporcjonalność. Istotą ich stosowania jest jednak możliwość prezentacji na dwuwymiarowej płaszczyźnie charakterystyki zjawiska lub obiektu (wybranych cech).

W zależności od poziomu nauczania znaki określające to samo zjawisko, obiekt czy zda-
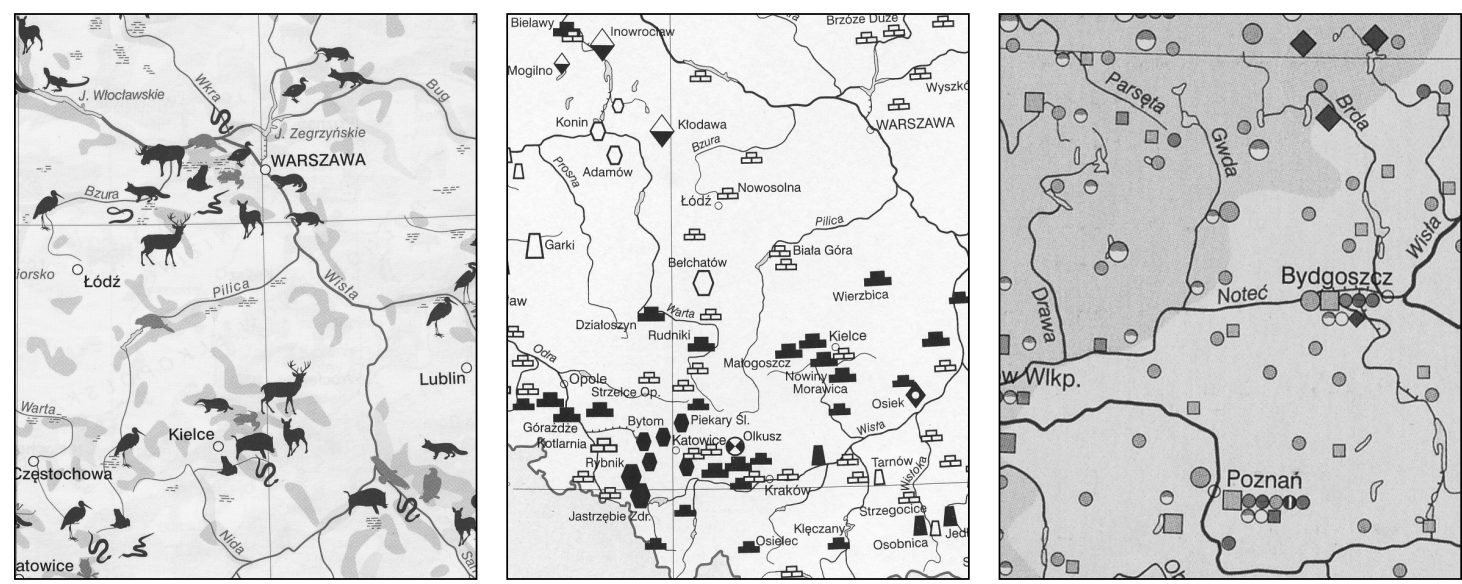

Ryc. 1. Fragmenty map z różnymi typami sygnatur: obrazkowe - komunikacja na poziomie szkoły podstawowej, sygnatury symboliczne i geometryczne - komunikacja na poziomie gimnazjum, liceum. Źródto: „Świat wokót nas. Atlas. Przyroda. Szkoła Podstawowa”, PPWK, Warszawa 2002, s. 33; „Atlas geograficzny. Świat, Polska", wyd. 4, Nowa Era, Warszawa 2004, s. 68; wyd. 5, Nowa Era, Warszawa 2005, s. 69

topograficznych, znaków liniowych - mających w terenie charakter liniowy i znaków powierzchniowych - dotyczących wybranego obszaru. Podczas doboru znaków, a zwłaszcza przy tworzeniu nowych ważna jest logika i konsekwencja w stosowaniu zmiennych graficznych, ponieważ zapewnia ona efektywność komunikacji. Zmienne graficzne wykorzystywane w kartografii - zaproponowane przez Jacques'a Bertina ${ }^{21}$ i zmodyfikowane przez Joannę Puszkarską ${ }^{22}$ to tak zwane zmienne tworzące obraz (położe-

\footnotetext{
$21 \mathrm{~J}$. Bertin, Semiologie graphique. Les diagram mes, les reseaux, les cartes, 2 ed., Paris-Le Huye 1973.

22 J. Puszkarska, Zmienne graficzne, s. 1 (http://zk.gik.pw.edu.pl/Edu-
} kacja/Wyklady/Grafika1.pdf, dostęp: 14.08.2014). rzenie mogą mieć różną postać. Dla uczniów szkoły podstawowej będą to znaki obrazkowe (często bliskie piktogramom), dla uczniów poziomu gimnazjalnego - znaki symboliczne, a dla uczniów liceum i studentów - symboliczne lub abstrakcyjne (ryc. 1).

\section{Pragmatyka - istota i zakres treści na mapach szkolnych}

Pragmatyka w kartografii to przede wszystkim taki dobór form przekazu graficznego, które budują treść mapy oraz zapewniają skuteczność w jej odbiorze - czytelność i porównywalność. Decyduje tu zatem także cel, który mapa ma realizować, oraz odbiorca, dla którego jest przeznaczona. Pragmatyka w kartografii szkol- 

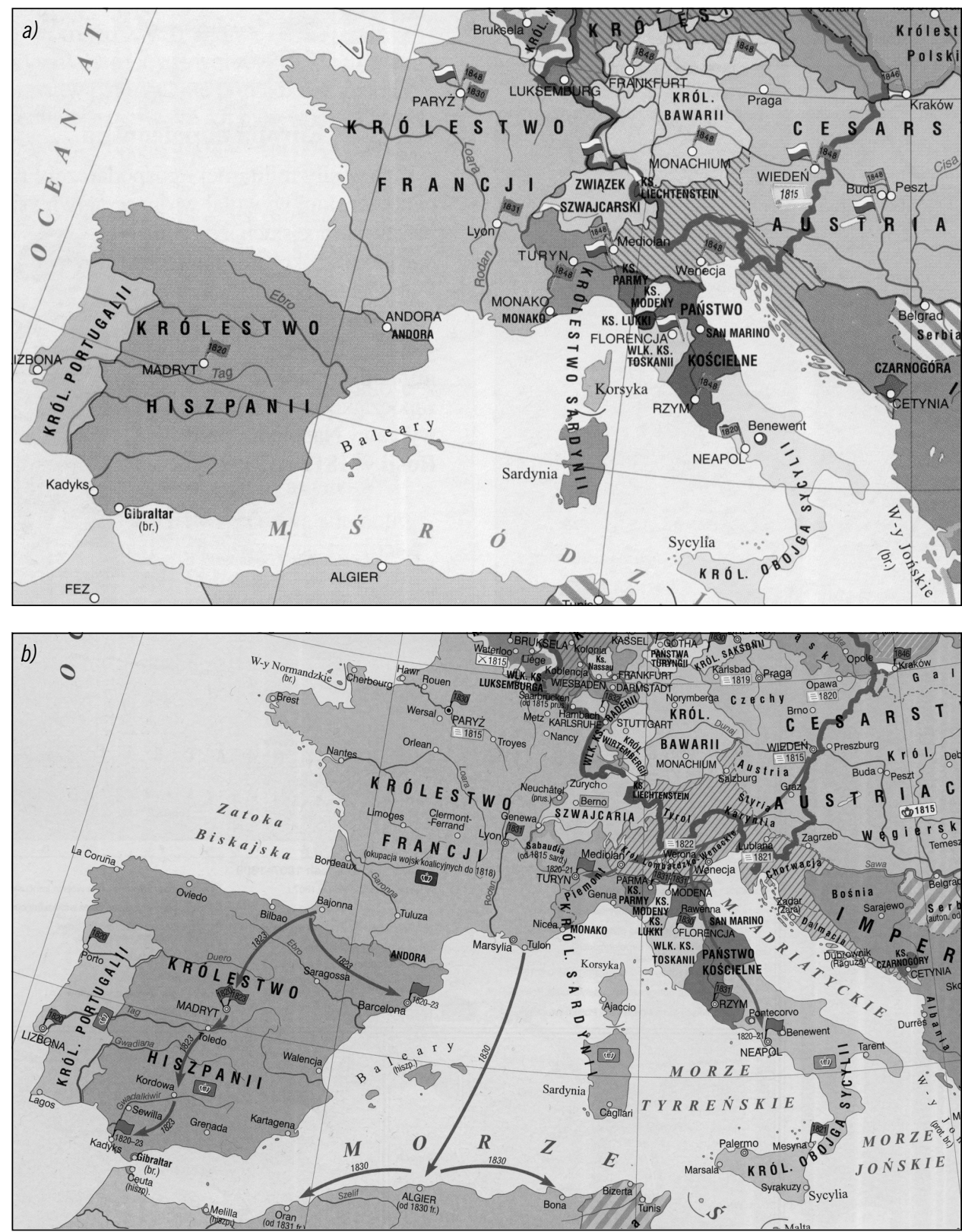

Ryc. 2. Fragmenty map historycznych z różnym nasyceniem treści: a) poziom podstawowy, b) poziom liceum.

Żródto: „Atlas historyczny. Szkoła Podstawowa”, wyd. 1, PPWK, Warszawa-Wroctaw 1999, s. 28; „Atlas historyczny. Liceum”, wyd. 1, Nowa Era, Warszawa 2008, s. 82

nej musi uwzględniać różne poziomy nauczania oraz określać istotę i zakres przekazywanych treści. Najłatwiej przybliżyć to można na przykładzie narracji historycznej, której specyficznymi cechami są diachroniczne i synchro- niczne struktury elementów obrazu historycznego o różnym nasyceniu $\mathrm{w}$ poszczególnych przedziałach czasowych i przestrzennych. Osadzanie zjawisk w czasie na mapie historycznej dokonywane jest przez jednoczesne oznaczanie 
ich w przestrzeni geograficznej ${ }^{23}$. Narracje kartograficzne tworzą wiedzę systemową.

W szkolnym nauczaniu historii stosowane są narracje kartograficzne tworzone z myślą o ich odbiorcach - uczniach poszczególnych stopni organizacyjnych szkół. Cechuje je prostota struktury, przystępność języka, odpowiednie nasycenie materiałami spostrzeżeniowymi, wyobrażeniowymi i pojęciowymi ze względu na poziom rozwoju intelektualnego i emocjonalnego. Obrazują to następujące przykłady fragmentów map do szkoły podstawowej i liceum (ryc. 2).

\section{Interpretacja ułatwiająca zrozumienie}

Pomiędzy znakami języka pisanego a znakami kartograficznymi zachodzą istotne różnice: proces czytania tekstu ma charakter liniowy,
Poniższe porównanie pokazuje, jak semantycznie bogatszy jest znak na mapie w odróżnieniu od znaku słownego, często jednoznacznego interpretacyjnie. Przy tym uświadamia, jak ważne jest także przestrzeganie zasad w odniesieniu do jednorodności stosowanych znaków, zwłaszcza na mapach przeznaczonych do użytku szkolnego (ryc. 3).

Mapa szkolna na różnych poziomach nauczania powinna charakteryzować się rygorystycznym podejściem do określania zakresu treści i możliwości nasycania jej znakami kartograficznymi.

Mapa stanie się dla ucznia źródłem wiadomości wówczas, gdy opanuje on pismo i język mapy w takim stopniu, że będzie mógł ją czytać ze zrozumieniem. Przyjmuje się, że umiejęt-

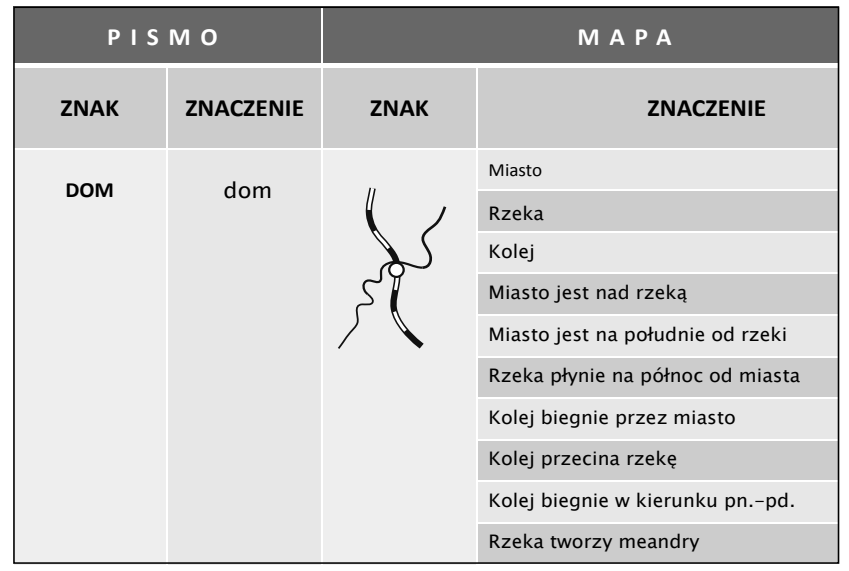

Ryc. 3. Różnica w semantyce znaków stownego i kartograficznego.

Żródto: L. Ratajski, ,Zasady logiczno-semiotyczne uporządkowania i standaryzacji znaków kartograficznych”, , Polski Przegląd Kartograficzny”, 3 (3), 1971, s. 109

a same litery są znakami nieciaghymi i jednakowo zorientowanymi, tekst pisany nie jest ograniczony wielkością miejsca (jeden wyraz nie zajmuje miejsca drugiego wyrazu). Mapa przemawia za pomocą sygnałów wizualnych i informuje o układach przestrzennych przedstawianej treści.

\footnotetext{
${ }^{23}$ A. Zielecki, Szkolna mapa historyczna jako narracja historyczno-dydaktyczna, w: Mapa w pracy historyka, red. T. Bogacz, B. Konopska, Wrocław 1999, s. 135 (Z Dziejów Kartografii, 11).

${ }^{24}$ A. Zielecki, Szkolna mapa, s. 137.
}

ności czytania map przez uczniów winny stać się jednym z podstawowych celów kształcących w nauczaniu historii ${ }^{24}$.

\section{Mapa jako pomoc w wyjaśnianiu procesów (zestawienie geografii $z$ historią)}

Wyższym „stopniem wtajemniczenia” w interpretacji mapy na poziomie szkolnym jest posługiwanie się nią dla zobrazowania i zrozumienia przez uczniów szerszych zjawisk i procesów politycznych, społecznych czy gospodarczych. Aby interpretacja była pełna, optymalne by- 
łoby łączenie treści historycznych i geograficznych na obu przedmiotach, a co za tym idzie wykorzystywanie jednocześnie map geograficznych i historycznych. Przybliżając uczniom np. współczesne oblicze polskiej gospodarki, powinno uwzględnić się obok mapy gospodarczej także mapę klimatyczną, mapę gleb, ukształtowania terenu wraz ze stosunkami wodnymi, jak również mapę historyczną z przemianami gospodarczymi, najlepiej w kilku przekrojach czasowych.

Z kolei omawiając np. relacje Polski z Zakonem Krzyżackim, obok mapy historycznej pokazującej układ granic z zasięgami terytorialnymi i ważniejsze wydarzenia dobrze byłoby włączyć do interpretacji mapę geograficzną, obrazującą m.in. specyfikę terenową. Idealnym rozwiązaniem byłoby, gdyby obraz geograficzny uwzględniał stan środowiska dla omawianego okresu historycznego. W tym ostatnim przypadku taka rekonstrukcja zależy już od stanu badań w zakresie geografii historycznej.

Przykładowe rozwiązania muszą natomiast w dużej mierze obejmować mapę multimedialną, ponieważ mapa statyczna, papierowa (ścienna lub atlasowa) nie spełni tych oczekiwań.

Wrażenie głębi, przestrzeni w rysunku komputerowym wydobywa się z wielką łatwością. Jest on wolny od wszelkiego rodzaju deformacji i zniekształceń (oprócz wynikających z opracowania redakcyjnego), które występują przy odręcznym cieniowaniu rysunku poziomicowego lub konstruowaniu modelu. Technika komputerowa pozwala na obserwację obiektu $\mathrm{z}$ dowolnej perspektywy i $\mathrm{w}$ różnym powiększeniu. Efektem są różne, optymalnie dobrane ujęcia przedstawień perspektywicznych, głównie ukształtowania terenu.

\section{Myślenie przestrzenne jako klucz do zrozumienia procesów geograficznych i historycznych oraz jako wartość trwała}

Utrwalanie w pamięci zjawisk przestrzennych, co ma zapewniać edukacja szkolna, wiąże się z jednej strony z możliwością powrotu do oglądanego obrazu/mapy, z drugiej - do różnorodności przekazów, swoistym bombardowaniem z różnych nośników informacji.
Zapamiętywanie to jeden z ważnych etapów prowadzących do postrzegania i rozumienia zjawisk oraz procesów (przede wszystkim historycznych i geograficznych) poprzez przestrzeń, ale to również włączanie obrazów przestrzennych do różnych innych działań mających zarówno wymiar teoretyczny, jak i praktyczny. Ideałem byłoby, aby po ukończeniu edukacji na poziomie szkolnym absolwent posiadł na zawsze nie tylko umiejętność rozumienia mapy i stałego jej użytkowania, ale także myślenia przestrzenią, co niezwykle wzbogaci jego wiedzę o otaczającym go świecie, a w wymiarze społecznym pozwoli podnieść na wyższy poziom tzw. kulturę kartograficzną.

Realizacji takich oczekiwań sprzyjają posiadane predyspozycje, ponieważ możliwość gromadzenia obrazów przestrzeni oraz ich utrwalanie ma także swoje źródło w specyfice ludzkiego umysłu. Jest on z jednej strony mocno zakorzeniony w przeszłości, wraz z nakierowaniem na międzypokoleniowy przekaz informacji, z drugiej zwrócony ku przyszłości i stymulowany przez marzenia, przewidywania i wizje ${ }^{25}$. Globalizacja jako istotny rys współczesnego świata, nasyconego elektroniczną techniką komunikowania się, jest tego wymownym efektem.

\section{Zakończenie}

Zaprezentowane treści skłaniają do kilku refleksji. Z przedstawionego materiału jednoznacznie wynika, że mapa to niedający się przecenić środek dydaktyczny, ważne narzędzie w procesie komunikacji edukacyjnej, stale udoskonalane technicznie i merytorycznie, w dużej mierze dzięki rozwojowi technik informatycznych. Narzędzie - trzeba dodać - jak się wydaje, coraz bardziej doceniane przez nauczycieli, w tym także uczących w szkołach dla dzieci i młodzieży niewidomej i niedowidzącej. Komunikacja z wykorzystaniem map dla tej grupy uczniów przebiega w podobny sposób, choć przygotowanie tych map pod względem redakcyjnym musi uwzględniać specyfikę ich percepcjii ${ }^{26}$.

\footnotetext{
25 P. Krajewski, Postrzeganie świata, s. 62.

26I. Krauze-Tomczyk, Polskie mapy dla niewidomych isłabo widzących, „Polski Przegląd Kartograficzny”, 33 (3), 2001, s. 237-240.
} 
Mapy dla niewidomych i niedowidzących to mapy drukowane na specjalnym podłożu w kolorach rozróżnialnych przez uczniów niedowidzących lub monochromatyczne (reliefowe) wykorzystujące alfabet Braille'a. Nowoczesne technologie na razie pozwolity na opracowanie map wybranych obiektów lub miejsc, łącząc je z GPS i plikami dźwiękowymi.

Inna refleksja wiąże się z faktem, że mapy w dydaktyce kojarzone są prawie wyłącznie z dwoma przedmiotami: geografią i historią. Gabinety przedmiotowe w szkołach poszufladkowały posiadany zasób kartograficzny na te dwie kategorie tematyczne - w treści artykułu wykazano, że niesłusznie. Mapa jednak - jeśli potraktować poważnie postulat postrzegania wszelkich zjawisk i procesów związanych z działalnością człowieka przez pryzmat przestrzeni - jawi się jako narzędzie uniwersalne, ponadprzedmiotowe. Dlatego też - jak się wydaje wskazane byłoby jej szersze wykorzystywanie także na innych zajęciach dydaktycznych, podejmujących zagadnienia związane m.in. z: literaturą (np. wątki tematyczne w utworach literackich a uwarunkowania przestrzenne), sztuką

\section{Literatura}

Achmatow I., Karamzin M., Attas gieograficzeskij, istoriczeskij i chronotogiczeskij rossijskogo gosudarstwa, izd. E. Ejnerlinga, Sankt-Pietierburg 1845.

Atlas geograficzny. Świat. Polska, , wyd. 4, Nowa Era, Warszawa 2004.

Atlas geograficzny. Świat. Polska, wyd. 5, Nowa Era, Warszawa 2005.

Atlas historyczny. Liceum, wyd. 1, Nowa Era, Warszawa 2008.

Atlas historyczny. Od starożytności do wspótczesności. Szkota podstawowa, wyd. 1, Nowa Era, Warszawa 2012.

Atlas historyczny. Szkota Podstawowa, wyd. 1, PPWK, Warszawa-Wrocław 1999.

Bednarek S., Pojmowanie kultury $i$ jej historii we wspótczesnych syntezach dziejów kultury polskiej, Wrocław 1995.

Bertin J., Semiologie graphique. Les diagram mes, les reseaux, les cartes, 2 ed. Paris-Le Huye 1973. (np. motywy artystyczne i ich środowiskowe źródła) czy kształtowaniem się idei i doktryn politycznych we współczesnym świecie (różnice generuje m.in. specyfika przestrzeni).

Nawiązując do głównego nurtu rozważań, czyli do geografii i historii w szkole, optymalnym rozwiązaniem na dziś - jak się wydaje - byłoby równoległe korzystanie $\mathrm{z}$ map geograficznych i historycznych na obu przedmiotach. W pespektywie natomiast - co jest już propozycją pod adresem autorów pomocy dydaktycznych - biorąc pod uwagę nowe technologie w kartografii i nowe potrzeby ujęć problemowych, powinno się dążyć do wykreowania map interaktywnych, które łączyłyby treści geograficzne z historycznymi i stałyby się uniwersalnym narzędziem w komunikacji edukacyjnej, przydatnym także w obrazowaniu innych zagadnień tematycznych. Takie podejście ograniczyłoby uciążliwości wynikające z braku korelacji programowej między przedmiotami, jak również pozwoliłoby na pełniejsze odejście od ciagle obecnych w polskiej szkole tradycyjnych podziałów na odrębne przedmioty.

Encyklopedia wiedzy o jezyku polskim, red. S. Urbańczyk, Wrocław-Warszawa-Kraków 1978.

Grot C., Jakich map należy używać na lekcjach historii, „Życie Szkoły”, 8/9, 1946, s. 197-199.

Hamilton Ch., Skuteczna komunikacja w biznesie, red. T. Rzepko, Warszawa 2011, s. 26.

Jelonek A., Rola masmediów i Internetu w dydaktyce (http://www.nauczyciele.mom.pl/publikacje/10/strona6.html, dostęp: 14.08.2014).

Kamińska A., Rola nowych technologii $w$ nauczaniu - przyktad fizyki, w: Nowe media $w$ edukacji, red. T. Lewowicki, B. Siemieniecki, Toruń 2012, s. 48-63.

Krajewski P., Postrzeganie świata jako funkcja techniki, w: Kultura-Nauka-Media. Jak media transformuja świat? Szanse i zagrożenia, red. P. Rudzki, Wrocław 2002, s. 55-61.

Krauze-Tomczyk I., Polskie mapy dla niewidomych i stabo widzacych, „Polski Przegląd Kartograficzny”, 33 (3), 2001, s. 237-240. 
Mtodzi ludzie, urodzeni po 1990 roku, wybieraja kreatywny styl życia (http://natablicy.pl/mlodzi-ludzie-urodzeni-po-1990-roku-wybieraja-kreatywny-styl-zycia,artykul.html?material_id=4feadb36142d5c8269000000\#zamknij, dostęp: 14.08.2014).

Montenello D.R., Cognitive map-design research in the twentieth century: Theoretical and empirical approaches, „Cartography and Geographic Information Science”, 29 (3), 2002, s. 283-304.

Mościcki H., Rola mapy w nauce o Polsce wspótczesnej, Lwów 1936.

Mościcki H., Wskazówki praktyczne dla nauczycieli historii $w$ szkotach średnich $i$ powszechnych, Warszawa 1925.

Olson J., Experience and the improvement of cartographic communications, "Cartographic Journal”, 12, 1975, s. 94-108.

Ostrowski W., Nowe mapy tematyczne $w$ atlasach szkolnych PPWK, „Polski Przegląd Kartograficzny”, 33 (3), 2001, s. 231-234.

Piskorz S., Wprowadzenie, w: Zarys dydaktyki geografii, red. S. Piskorz, Warszawa 1997, s. $14-15$.
Puszkarska J., Zmienne graficzne (http://zk.gik. pw.edu.pl/Edukacja/Wyklady/Grafika1.pdf, dostęp: 14 sierpnia 2014).

Rippel R., Multimedia wedukacjipolonistycznej, „Forum Humanistów”, 2, 2000, s. 22-26.

Romer E., Atlas geograficzny i historyczny dla IV klasy gimnazjum, Książnica-Atlas, Lwów 1936.

Schrader J.F., Atlas de géographie historique, Paris 1893.

Schrader J.F., Atlas de géographie moderne, Paris 1890.

Spruner K., Historisch-Geographischer Schul-Atlas, Gotha 1890.

Świat wokót nas. Atlas. Przyroda. Szkota Podstawowa, PPWK, Warszawa 2002.

Zielecki A., Szkolna mapa historyczna jako narracja historyczno-dydaktyczna, w: Mapa $w$ pracy historyka, red. T. Bogacz, B. Konopska, Wrocław 1999, s. 131-144 (Z Dziejów Kartografii, 11).

\section{The concept of using interactive cartographic presentations as a tool in the process of geographical-historical education}

\section{Summary}

Cartographic documents in the form of maps and atlases are one of the forms facilitating communication in the relation between the teacher and the pupil in the process of knowledge transmission, mainly in the fields of geography and history. Spatial information on places, phenomena and events, both natural and socio-economic ones, taking place currently and in the past is presented on maps in the form of cartographic signs. New possibilities of using the maps appeared together with the development of computer technologies.

The present article approaches a few important aspects of the subject, namely how the process of using the maps as a means of communication should proceed at different levels of education, how technological achievements affect the im- provement of the map, and how this influences the potential effectiveness of education and the possibility of the pupils using the acquired abilities in the further out-of-school practice.

A geographical or a historical map, both in its traditional, paper form and in a multimedia edition, is an effective tool of communication after having fulfilled a few conditions, e.g. compatibility of the map's content with the curriculum and the information capacity of the scale in which it is presented as well as the map's graphics prepared according to the principles of cartographic semiotics. Both these conditions - the first related to the map's content and the other connected with its graphics - are closely related to the user's features. In the case of the receivers of school maps, the users 
are characterized by different perception and experience, depending on age. Different requirements concerning the cartographic form of communication are imposed by pupils with eye defects (visually impaired, blind). At the first stage of teaching both geography and history, the teacher, who teaches how to interpret the map through discussion and explanation, plays a key role in the process of communication between the map and the pupil. On the high school level, communication in the relation between the map and the student acquires a direct dimension and it does not require the teacher's participation any more.

Słowa kluczowe: dydaktyka historii, dydaktyka geografii, edukacja, mapa szkolna, narzędzia edukacyjne

Keywords: didactics of history, didactics of geography, education, school map, education tools

dr Teresa Bogacz - wykładowca w Wyższej Szkole Zarządzania „Edukacja” we Wrocławiu, członek Zespołu Historii Kartografii przy Instytucie Historii Nauki PAN

(e-mail teresa.bogacz@wp.pl)

dr hab. Beata Konopska - kartograf i historyk, zatrudniona w Instytucie Geodezji i Kartografii w Warszawie, wiceprzewodnicząca Zespołu Historii Kartografii przy Instytucie Historii Nauki PAN

(e-mail: beata.konopska@igik.edu.pl) 